No 4657 January 31, 1959

behaviour of the many different types of brakes and to record the conditions to which they are subjected in service. Surface temperature is one of the many important variables, and both its measurement and calculation are of vital importance.

The Test House contains test dynamometers of the inertia type for examining experimental materials under conditions that can be encountered in service. The machines are, in the main, automatic in operation and are self-recording, and permit a much closer control and therefore a better opportunity for studying the various factors affecting behaviour. The larger machines are designed to fit the types of brakes used on aircraft, heavy transport, railways and industrial brakes, while on the smaller machines provision is made to fit brakes varying from automotive to bicycle. The workshop adjoining the Test House is fully equipped to make all but the large parts of the various test machines, and the laboratories situated on a second floor over the workshop and test car garage are concerned with the design and construction of the various servo and other devices needed for the operation and control of the machines. Towards the end of the wing is a test car garage which houses a fleet of test vehicles, including motorcycles, large and small saloon cars, high-performance sports cars, lorries and buses. The vehicles are all fitted with instruments of various types which, in effect, make them mobile laboratories.
Although the laboratories stand adjacent to the factory, it was considered essential for them to be self-contained, and to this end the pilot-plant laboratory is equipped with all the production plant and finishing apparatus required to make prototype materials. Such provision not only enables development staff to plan their work more easily, but also frees production plant in the factory from costly interruptions. One section of this wing is allocated to the Production Plant Development Section, which carries out all the proving trials that may be necessary on new plant of a novel design. This design section works not only in close co-operation with the pilot plant section, but also with those chemists and physicists who are concerned with ideas still only in their embryonic stage.

Even this brief description of the laboratories should serve to show that the study of friction and the manufacture of friction materials involves contributions from chemists, engineers, metallurgists, mathematicians, statisticians, physicists and physical chemists. Indeed, the added interest gained from co-operating with so many different disciplines serves to render a fascinating study exhilarating.

The architects for the new Ferodo Research Laboratories were Messrs. Ashworth and Fletcher; the quantity surveyors Messrs. Worrell and Kelly; and the consulting engineers Messrs. R. W. Gregory and Partners.

\title{
THE SCIENCE MASTERS' ASSOCIATION
}

\section{ANNUAL MEETING}

$\mathrm{T}$ 'HE annual meeting of the Science Masters' Association was held in University College and Queen Elizabeth College, London, during December 30-January 2, and was attended by a thousand members and many guests; this number included members from Canada, India, Pakistan, South and West Africa, and the United States. Among them was Prof. R. W. Lefler, of Purdue University, Indiana, who is at present acting as adviser in physics to the Nationalist University in Formosa.

The meeting began with the presidential address by Sir Lawrence Bragg, who outlined the past history and present policy of the Royal Institution. The second evening was occupied by a lecture by Dr. $\mathrm{H}$. Lister on the recent Trans-Antarctic Expedition; this was notable for the splendid coloured slides.

The programme of morning lectures by members of the staff of University College, together with guest lecturers from Harwell, the Brunel College of Technology, the London Institute of Education, and Woodberry Down School, London, has already been given in Nature (December 6, p. 1554). One of these, that by Mr. H. G. Conway, of Short Brothers and Harland, Belfast, on "New Engineering Problems in Aeronautics", was attended by Air Marshal Sir Owen Jones, president of the Institution of Mechanical Engineers, and other members of the Institution.

The Manufacturers' and Publishers' Exhibitions, held in University College, were larger than ever before, with the result that the exhibition of apparatus and other items brought by members had to be housed in Queen Elizabeth College. Among these exhibits was an intensely interesting historic one, namely,
Faraday's bible, shown by Mr. E. H. Duckworth, of Cheltenham; this contained Faraday's autograph and his original marking of important texts.

The Science and Religion Group was addressed by the Rev. Aubrey Vine, general secretary of the Free Church Federal Council.

An innovation was the organization, at the suggestion of Mr. D. G. Chisman, education officer of the Royal Institute of Chemistry, of evening receptions by that Institute and by the Institutes of Physics and of Biology. These were much appreciated by members, as was shown by the fact that applications to attend far exceeded the available accommoda. tion. The afternoons were occupied by visits to university departments and to factories in or near London; for other members there were exhibitions of scientific films.

At the business meeting of the Association $\mathrm{Mr}$. D. G. James, vice-chancellor of the University of Southampton, was elected president for the ensuing year : Dr. H. F. Boulind, of the University of Cam. bridge Department of Education, was elected chairman, and Mr. H. Lockett, of Taunton's School, Southampton, became the new annual meeting secretary. It was announced that a summer meeting would be held, during July 28-31, in the Durham Colleges of the University of Durham. The next annual meeting will be in the University of Southampton, during December 29-January 1, 1960.

The second half of the business meeting was occupied with the discussion of a resolution, moved by Mr. D. N. Underwood and Mr. E. Chanter, which read : "that this meeting disapproves of the contin- 
ued teaching of General Science as a substitute for the separate sciences". The chairman, Mr. Charles Holt, said that it was somewhat unusual for resolutions of this kind to be brought forward at the business meeting, but that the General Committee had decided that a useful purpose would be served if it were diseussed. The Committee had always tried to avoid "coming down heavily on any particular side in science, because it took the view that members were so differently situated that they might find they had different needs at different stages of the work".

Mr. Underwood said the decision to move the resolution had been taken during the annual meeting last year at Leeds; coneern on the subject had also been shown in articles in the School Science Review and in many letters and comments which the proposers had received in favour of the resolution. They were concerned chiefly with the effect of the teaching of general science on potential scientists, and not so much with that on the weaker grammar school and modern school pupil. It was a fallacy to think that physics, chemistry, and biology could be lumped together as general science; they were different disciplines and should be taught by experts. General science meant reduced time for science and provided little opportunity for practical work.

Mr. Chanter, in seconding the motion, said that in general science "one had to go quickly from one thing to another and the pupil never really got his teeth into anything". He did not believe that was real education at all.

The discussion was opened by a member who said that the sciences were humanities, and that the most human things about them were the barriers between them; the thing about chemistry which made it not physics was one of the most charming things.

Mr. J. A. Storer suggested an amendment, which was supported by Mr. D. Lewis (Bristol). This was later withdrawn after Mr. R. H. Dyball (City of London School) had proposed the altered wording "that this meeting disapproves of the continued teaching of general science on an inadequate time allowance". Mr. H. P. Ramage (Gresham's School, Holt) supported Mr. Dyball, and said that if physics, chemistry, and biology, with some geology and astronomy, were studied separately, it was still general science in the Association's meaning of the term. He would like to see enough time given to teach all these subjects up to Advanced $(A)$ level; but the original resolution, if earried, would be misquoted and give a very wrong impression. After further discussion, the arnendment proposed by Mr. Dyball was carried by an overwhelming majority.
The second discussion was on the Association's policy statement, "Science and Education", which has been widely distributed in educational circles. This was introduced by the chairman-elect, Dr. H. F. Boulind, who said that the main reason for the state. ment was "dissatisfaction with the present state of science teaching; the country is not producing the scientists, technicians, and technologists required". Secondly, it is science which is shaping the modern world, and some reasonable standard of scientific understanding is essential for everyone. The statement was produced by a sub-committee of two physicists, two chemists, and two biologists, and had been almost unanimously approved by the General Committee. It had been discussed with the Minister of Education and with Under-Secretaries, with the Central Advisory Committee, and with the Secondary School Examinations Committee; later work had been undertaken by specialist panels. Among the recommendations were the following : "that all pupils should follow an adequate course in science up to the end of the fifth-form year"; that "science should be studied by all pupils in the sixth form", and that "subject specialization should be retained in the sixth form but that $A$ level syllabuses should be reduced in factual content".

In the discussion, a member said the problem should be considered from the point of view of the nonscientist; many important subjects are left out at Ordinary $(O)$ level, so that pupils leaving at the age of 16 never touch them. Several members commented that the examining boards are favourable to a reduction in the factual content of examinations. Mr. W. H. Dovell (Lancing) thought that there are too many topics of interest only to the specialist in the $O$ level course. He also asked for Dr. Boulind's views on the number of teaching periods a week. Dr. Boulind, in reply, said that nine periods a week should be adequate up to $O$ level. Many members dissented at once. Mr. G. A. Lees (Collyer's School, Horsham) said that the policy statement was a very good effort, but that practical details as to time allowances were much more important. Further discussion centred on the question whether junior school science teaching should all be in the hands of one teacher or in those of specialists; on the influence which the Association might exert in introducing science into the common entrance examination for public schools; and on the effect of the statement on science teaching in modern schools and comprehensive schools. The chairman, in closing the discussion, mentioned that Dr. Boulind had been mainly responsible for the policy statement.

\section{MANAGEMENT THEORY}

HE third booklet in the "Problems of Progress in
Industry" issued by the Department of Industrial
and Scientific Research (Management and Techno-
logy. By Joan Woodward. Pp. 40. London : H.M.
Stationery Office, 1958. 2s. 6d. net) describes a survey
of the management organization of a hundred firms
in south Essex. The survey attempted to discover
whether the principles of organization laid down by
an expanding body of management theory correlate
with business success when put into practice. The survey was made between 1953 and 1957 by the Human Relations Research Unit of the South-East Essex Technical College, and after a basic survey of 91 per cent of manufacturing firms in south Essex with more than a hundred employees, twenty firms were studied more fully and detailed case-studies made of three firms in which production systems were mixed or changing. A full report of the research with a discussion of its theoretical implications is projected shortly under the title "Management 